\title{
Group II metabotropic glutamate receptors and schizophrenia
}

\author{
José L. Moreno ${ }^{1,3}$, Stuart C. Sealfon ${ }^{2,4}$, and Javier González-Maeso 1,2,3 \\ Javier González-Maeso: Javier.Maeso@mssm.edu \\ ${ }^{1}$ Department of Psychiatry, Mount Sinai School of Medicine, New York, NY 10029, USA \\ 2 Department of Neurology, Mount Sinai School of Medicine, New York, NY 10029, USA \\ 3 Division of Basic Neuroscience, Mount Sinai School of Medicine, New York, NY 10029, USA \\ ${ }^{4}$ Center for Translational Systems Biology, Mount Sinai School of Medicine, New York, NY 10029, \\ USA
}

\section{Abstract}

Schizophrenia is one of the most common mental illnesses, with hereditary and environmental factors important for its etiology. All antipsychotics have in common a high affinity for monoaminergic receptors. Whereas hallucinations and delusions usually respond to typical (haloperidol-like) and atypical (clozapine-like) monoaminergic antipsychotics, their efficacy in improving negative symptoms and cognitive deficits remains inadequate. In addition, devastating side effects are a common characteristic of monoaminergic antipsychotics. Recent biochemical, preclinical and clinical findings support group II metabotropic glutamate receptors (mGluR2 and mGluR3) as a new approach to treat schizophrenia. This paper reviews the status of general knowledge of mGluR2 and mGluR3 in the psychopharmacology, genetics and neuropathology of schizophrenia

\section{Keywords}

Schizophrenia; Antipsychotics; G protein-coupled receptors (GPCR); Serotonin receptors; 5$\mathrm{HT}_{2 \mathrm{~A}}$; Metabotropic glutamate receptors; mGluR2; mGluR3

\section{Introduction}

Schizophrenia is a chronic mental disorder that affects approximately $1 \%$ of the population worldwide with similar prevalence throughout diverse cultures and geographic areas [1-5]. The symptoms of schizophrenia include "positive"' symptoms (e.g., hallucinations, delusions, paranoia), negative symptoms (e.g., social withdrawal, apathy, abnormal emotional responses), and cognitive deficiencies such as impaired memory, attention deficit, and reduced executive functioning. Serendipity played a role in the discovery of both the first (typical, haloperidollike) and second (atypical, clozapine-like) generation of antipsychotics. The first antipsychotic chlorpromazine was discovered in 1952 as an antihistaminic that decreased psychosis [6]. Haloperidol was first developed as a pain reliever [7], and clozapine was originally a "tricyclic antidepressant with neuroleptic properties" $[8,9]$. To date, both the mechanism of action of antipsychotics and the pathogenesis of the disease remain largely unknown.

Since schizophrenia is incurable, treatment with antipsychotics typically continues for life. Typical antipsychotics do not resolve negative symptoms, may fail to improve positive symptoms, and worsen cognitive symptoms in some patients [10,11]. Atypical antipsychotics 
have a reduced risk of extrapyramidal symptoms, and have become the first-line treatment for schizophrenia $[12,13]$. However, whereas positive symptoms usually respond to antipsychotic medication, success in treating schizophrenia remains limited by low efficacy of the neuroleptics in the treatment of negative symptoms and cognitive deficits $[14,15]$. Clozapine was discovered more than 50 years ago and approved by the FDA in 1989, yet it remains the only antipsychotic medication with established efficacy in treatment-resistant schizophrenia patients. Clozapine could also be beneficial for less severely ill patients who show only partial response to other antipsychotic drugs. Despite its efficacy, clozapine has substantial undesirable effects on metabolic parameters causing weight gain, glucose abnormalities, hypertriglyceridemia, and hypertension. Reports have also shown that $1-2 \%$ of patients who take clozapine will develop agranulocytosis, a sometimes fatal side effect that severely limits the use of the most efficacious antischizophrenia drug [16-19]. All the antipsychotic medications currently prescribed have in common a high affinity for monoaminergic receptors. Notably, recent preclinical and clinical findings suggest metabotropic glutamate receptors 2 and/or 3 as a new target to treat schizophrenia [20-24]. Treatment of schizophrenic patients with the mGluR2/3 agonist LY2140023 led to an improvement of both positive and negative symptoms without significant side effects compared to placebo [25]. Studies with twin, family and adoption suggest that schizophrenia results from a combination of predisposing genes and hazardous environmental factors [26,27]. Here, we review the potential implications of mGluR2 and mGluR3 in the pharmacological, genetic and epigenetic aspects of the disorder.

\section{Group II metabotropic glutamate receptors}

L-Glutamate is the major excitatory neurotransmitter in the mammalian CNS, acting through both ligand-gated ion channels and G protein-coupled receptors (GPCRs). The ionotropic glutamate receptors are multimeric assemblies of four or five subunits, and are subdivided into three groups (AMPA, NMDA, and kainate receptors) [28]. GPCRs represent the largest family of signal transduction membrane proteins, and a major target for therapeutic drugs. All known GPCRs have a common structural template composed by seven membrane-spanning alpha helices joined by hydrophilic loops [29,30]. The three major families of GPCRs include the rhodopsin-like receptors (family A), the glucagon-related receptors (family B), and metabotropic glutamate-related receptors (family C). Family $\mathrm{C}$ is characterized by a large amino terminus extracellular domain that consists of two lobes separated by a large cleft that contains the agonist binding site [31,32]. This family includes the metabotropic glutamate receptors (mGluRs), the $\gamma$-aminobutyric acid $\left(\mathrm{GABA}_{\mathrm{B}}\right)$ receptor, and the calcium sensing receptors. Metabotropic glutamate receptors have been subdivided into three groups, based on sequence similarity, pharmacology, and $\mathrm{G}$ protein coupling. The group I mGluRs is represented by mGluR1 and mGluR5, both coupled to $\mathrm{G}_{\mathrm{q} / 11}$ proteins and activation of phospholipase $\mathrm{C}$. The group II (mGluR2 and mGluR3) and group III (mGluR4, mGluR6, mGluR7 and mGluR8) receptors are coupled to $\mathrm{G}_{\mathrm{i} / \mathrm{o}}$ proteins and typically inhibit adenylyl cyclase activity. With the exception of the mGluR6 isoform, which is expressed restrictedly at the postsynaptic site of retinal ON-bipolar cells, metabotropic glutamate receptors are widely distributed in the brain.

Although much biochemical and biophysical data are consistent with the ability of GPCRs to bind and activate $\mathrm{G}$ proteins in a monomeric form [33-38], many recent studies support the hypothesis that $\mathrm{G}$ protein coupling in cell membranes involves the formation of GPCR homoand heterodimers or higher order oligomers [39-41]. In particular, much evidence indicates that family $\mathrm{C}$ receptors exist and function as dimers [31]. Thus, the co-assembly of two nonfunctional GPCRs, GB1 and GB2, is required for the expression of functional GABA receptors, and the heterodimer $\mathrm{GABA}_{\mathrm{B}}$ receptor has been demonstrated to activate through a mechanism of trans-activation [42-44]. The functional significance of family $\mathrm{C}$ receptor dimerization is further supported by the demonstration that a closed state of both binding domains in the homodimeric mGluR5 is required for full activity [45], and that mGluR1 [46] 
and mGluR5 [47] are expressed in the cell membrane as a dimer, not as a higher order oligomer. The crystal structure of the amino terminus ligand-binding domain of the mGluR1 receptor presents a disulphide bridge connecting the two protomers [48,49]. Similarly, disulphide bonding within the amino terminus domains of mGluR5 and the calcium-sensing receptor has been reported to be important for covalent dimerization [50]. In addition, the expression of heterocomplexes between rhodopsin-like and metabotropic glutamate receptors have been reported for mGluR5, dopamine $\mathrm{D}_{2}$, and adenosine $\mathrm{A}_{2 \mathrm{~A}}$ [51,52], and for mGluR2 and serotonin $5-\mathrm{HT}_{2 \mathrm{~A}}$ receptors [53], thus further complicating the interpretation of signaling through metabotropic glutamate receptors.

\section{Group II metabotropic glutamate receptors as a new antipsychotic target}

The lack of clear pathological lesions in schizophrenia represents one of the main limitations for research on this disease using rodent models. Psychotomimetic drugs such as phenyclidine (PCP) and lysergic acid diethylamide (LSD) induce schizophrenia-like psychosis in humans and represent in mouse a pharmacological tool that has led to a better understanding of the neurochemical basis underlying schizophrenia and psychosis [54-57]. A single dose of PCP has been shown to intensify the symptoms in patients with schizophrenia, to produce hallucinations, and to reduce cognitive ability. In addition, acute PCP administration in rodents has been shown to elicit deficits in pre-pulse inhibition (PPI) of the startle response, a measure of sensorimotor gating deficits, to increase locomotor activity, to decrease social recognition, and to produce cognitive deficits of particular relevance to schizophrenia [58]. Studies with healthy volunteers showed similarities between the early stages of schizophrenia and the psychological effects induced by the LSD-like hallucinogen psilocybin [59]. The cellular and behavioral responses induced by hallucinogens are abolished in serotonin $5-\mathrm{HT}_{2 \mathrm{~A}}$ knock-out mice $[60,61]$. The complexity of schizophrenia makes it unfeasible to mimic the entire syndrome in mouse models. However, all these findings suggest that PCP-like and LSD-like drugs may be used as tools to model specific signs or symptoms associated with schizophrenia.

The demonstration in rodents that mGluR2/3 activation attenuates the effects of PCP on locomotion and working memory [62], and that suppresses the head-twitch response induced by the hallucinogenic 5- $\mathrm{HT}_{2 \mathrm{~A}}$ receptor agonist DOI [63], led to a tremendous amount of research showing functional and behavioral interactions between $5-\mathrm{HT}_{2 \mathrm{~A}}, \mathrm{mGluR} 2 / 3$, and NMDA receptors (see [57] for review). Studies in healthy human subjects reported that the behavioral effects of ketamine are disrupted by the mGluR2/3 agonist LY354740 [64]. Recent clinical trials support the significance of mGluR $2 / 3$ agonists as a new class of antipsychotics [25]. Thus, treated patients with LY2140023 showed significant improvements in both positive and negative symptoms of schizophrenia. Importantly, patients taking the LY2140023 did not show Parkinsonian side effects. Moreover, in contrast to atypical antipsychotics such as clozapine and olanzapine, the mGluR2/3 agonist did not result in undesirable effects on metabolic parameters. A long-standing question was whether mGluR2, mGluR3 or both are responsible for the antipsychotic effects of the mGluR2/3 agonists. Recent preclinical results in mouse models together with studies of allelic variation in humans suggest different roles for mGluR 2 and mGluR 3 in the mechanism of action of glutamate antipsychotics and the genetic link to schizophrenia.

\section{Antipsychotic-like effects in mouse are mGluR2, and not mGluR3, dependent}

The absence of selective orthosteric ligands has precluded detailed studies on the physiological and behavioral significance of mGluR 2 and mGluR3 for the mechanism of action of glutamate antipsychotics. Experiments with mGluR2 knock-out mice suggested that mGluR2 mediated the inhibition of the PCP-induced locomotor activity by the mGluR2/3 agonist LY314582 [65]. Concurrent studies with LY404039 [66] and LY379268 [67] provided evidence that the 
effects of the mGluR2/3 agonists blocking the locomotor activity induced by PCP and amphetamine are abolished in mGluR2 knock-out mice, and are unaffected in mGluR3 knockout mice. These data suggest that mGluR2, and not mGluR3, is the receptor responsible for the antipsychotic-like effects of the mGluR2/3 agonists in murine models.

The great majority of GPCR ligands used in the clinic and in basic research are orthosteric ligands (i.e., agonists, antagonists, and inverse agonists) that compete with endogenous ligands for the same binding site. Allosteric ligands modulate receptor function by binding not to the orthostheric site but to different regions in the receptor, the allosteric sites [68]. Interestingly, positive allosteric modulators of mGluR2 have behavioral effects similar to mGluR2/3 orthosteric agonists. The mGluR2 positive allosteric modulator LY487379 reduced the PCPand amphetamine-induced locomotion activity in a comparable manner to the allosteric mGluR2/3 agonist LY379268 [69]. In the same context, the mGluR2 positive allosteric modulator biphenyl-indanone A (BINA) blocks the head-twitch behavioral response induced by the hallucinogenic 5- $\mathrm{HT}_{2 \mathrm{~A}}$ agonist $\mathrm{DOB}$ [70]. Since allosteric modulators are unable to induce a functional response in the absence of orthosteric agonists, the effects of LY487379 and BINA on the behavioral effects of psychotomimetic drugs suggest that the allosteric modulators potentiate the mGluR2-dependent responses induced by the endogenous agonist glutamate.

The mGluR2 is likely to be responsible for the effects of antipsychotic mGluR2/3 agonists, and all the clozapine-like atypical antipsychotics have a high affinity for the $5-\mathrm{HT}_{2 \mathrm{~A}}$ receptor. The functional and behavioral interaction between $5-\mathrm{HT}_{2 \mathrm{~A}}$ and mGluR2 receptors is well established (Fig. 1), and activation of mGluR2 inhibits the cellular, electrophysiological, and behavioral responses induced by PCP-like and LSD-like psychotomimetic drugs (see [57] for review). Recent findings showed that $5-\mathrm{HT}_{2 \mathrm{~A}}$ and mGluR2 co-localize in cortical pyramidal neurons and form a receptor heterocomplex [53,57]. Interestingly, chronic treatment with the hallucinogenic $5-\mathrm{HT}_{2 \mathrm{~A}}$ agonist $\mathrm{DOB}$ alters the behavioral responses to the mGluR2/3 agonist LY379268 [71]. In addition, the locomotor activity induced by the mGluR2/3 antagonist LY341495 is reversed by antipsychotic drugs [72], and decreased in 5- $\mathrm{HT}_{2 \mathrm{~A}}$ knock out mice [53,57]. These and other data [57], together with the expression of 5- $\mathrm{HT}_{2 \mathrm{~A}}$ and $\mathrm{mGluR2}$ as a receptor heterocomplex in mouse and human brain $[53,57]$, suggest that the $5-\mathrm{HT}_{2 \mathrm{~A}}-\mathrm{mGluR} 2$ heterocomplex might represent a new target for antipsychotic therapies (Fig. 1). On the other hand, the blockage of the PCP-induced hyperlocomotion elicited by high doses of clozapine, risperidone, and olanzapine is not affected in mGluR2/3 double-knock out mice $[25,66]$. Although the risks of extrapyramidal symptoms are much less with atypical antipsychotics when compared to haloperidol, it has been reported that high doses of clozapine and other atypical antipsychotics produce motor suppression and catalepsy in rodents [73]. Since all atypical antipsychotics have a high affinity for the 5- $\mathrm{HT}_{2 \mathrm{~A}}$ and a modest affinity for the dopamine $\mathrm{D}_{2}$ receptor, further investigations with lower and therapeutically relevant doses of clozapine-like drugs are necessary to determine whether the $5-\mathrm{HT}_{2 \mathrm{~A}}-\mathrm{mGluR} 2$ complex is fully or in part responsible for the effects of atypical antipsychotics, as well as for the effects of glutamate antipsychotics.

\section{GRM2 and GRM3 genes in schizophrenia}

Twin studies show the existence of a genetic predisposition to schizophrenia, with estimates of heritability of risk at 73-90\% [74-76]. While other factors besides genetics are definitely involved, investigation of the genetic alterations responsible for schizophrenia represents a useful approach to better understand the cause of the disease [27]. Metabotropic glutamate receptor 2 gene (GRM2) has been mapped to chromosome 3p21.1-p21.2 [77], and linkage studies of schizophrenia show no positive results regarding this region [78-83]. The polymorphisms identified in the coding exons of GRM2 revealed ten missense mutations and 
one silent mutation [84]. However, these polymorphisms did not show statistically significant differences in schizophrenics and controls [84]. Further investigation with different cohorts might be necessary to better understand the potential role of the polymorphisms of the human GRM2 in receptor function, and to extend our knowledge of a potential association between SNPs in GRM2 and schizophrenia. In contrast to GRM3 (see below), no alternative splicing of GRM2 is expressed in human brain [85-87].

Metabotropic glutamate receptor 3 gene (GRM3) has been mapped to chromosome 7q21.1q21.2 [88], and several linkage studies reported one of the schizophrenia susceptibility loci as located in the proximity of the GRM3 region [78-80,82,83]. A unique case was reported with familial 7q21 reciprocal translocation and childhood-onset schizophrenia (COS) [89]. Polymorphisms in GRM3 have been associated with negative symptom improvement with clozapine [90]. Combined genomic and neurobiological approaches showed that GRM3 genotype affects cognition as well as prefrontal and hippocampal physiological responses [91], which was hypothesized as an increased risk for schizophrenia. The SNP proposed as associated with schizophrenia (rs6465084) showed lower levels of prefrontal $\mathrm{N}$-acetylaspartate (NAA), which is a reservoir for glutamate [91,92]. Catechol-o-methyltransferase (COMT) degrades catecholamines such as dopamine, serotonin adrenaline, and noradrenaline. Epistatis between COMT genotypes or haplotypes and SNPs in GRM3 has been explored showing association with working memory $[93,94]$. Concurrently, these data suggest an association of SNPs in GRM3 and schizophrenia, yet the potential link between genetic variations in GRM3 and schizophrenia remains debatable. First, genome-wide scans have implicated several regions of the genome; however, meta-analysis showed that the GRM3 locus did not reach statistical significance as implicated in schizophrenia [27]. Second, while five studies found association between individual SNPs and/or haplotypes in GRM3 and schizophrenia [91,93,95-97], eight studies including one meta-analysis did not [83,98-104]. Among the five positive studies, the research findings showing associations have not been consistent for the specific SNP patterns. It is therefore not established that GRM3 variants play a major role in predisposing to schizophrenia. Furthermore, since all SNPs within GRM3 are either noncoding or synonymous, the mechanisms underlying the genetic associations between polymorphisms in GRM3 and schizophrenia remain controversial. Recent evidences indicate that silent SNPs may result in different three-dimensional folding patterns of the transcribed mRNA that can affect mRNA degradation and in vivo protein folding and, consequently, protein function [105-107]. However, most of the studies suggest that the level of expression of $m G l u R 3$ mRNA is unaffected in schizophrenia brain (see below). Alternative pre-mRNA splicing also represents an important mechanism involved in the generation of transcript and protein diversity [86]. Alternative splicing of GRM3 studies in human brain reported four splice variants: full-length GRM3 (2.8 kb), GRM3 with exon 2 deleted (GRM3 $\Delta 2,2.2 \mathrm{~kb})$, GRM3 with exon 4 deleted (GRM $3 \Delta 4,1.8 \mathrm{~kb}$ ), and GRM3 with exons 2 and 3 deleted (GRM $3 \Delta 2 \Delta 3$, $1.4 \mathrm{~kb}$ ) [87]. The most abundant variant GRM $3 \Delta 4$ corresponds with a truncated protein with a conserved extracellular ligand binding domain, absence of seven-transmembrane domains, and a 96-amino acid C-terminus. A SNP in GRM3 was found to correlate with the expression of the GRM $3 \Delta 4$ splice variant [108], but it is not the GRM3 variant rs6465084 that has been reported to affect cognition (see above and [91]). In conclusion, while the current data concerning GRM3 do not allow rejection of the null hypothesis, to date there is no clear association between any SNP, genotype, or haplotype with schizophrenia.

\section{Level of expression of mGluR2 and mGluR3 in schizophrenia}

The majority of the findings in post-mortem human brain suggest that the level of expression of $m$ GluR3 mRNA is unaffected in schizophrenia [53,91,109-112]. Our current understanding of how the genome regulates gene expression and function is limited. However, the unaffected level of expression of $m G l u R 3$ mRNA is supported by the hypothesis that variation in GRM3 
is not associated with schizophrenia (see above). Fewer studies have investigated the level of expression of $m G l u R 2$ mRNA in post-mortem human brain of schizophrenic subjects. Semiquantitative approaches such as in situ hybridization have reported unaffected $m G l u R 2$ mRNA expression in thalamus [110], and higher $m G l u R 2$ mRNA expression in the prefrontal cortex white matter [111]. However, quantitative real-time PCR assays shown lower level of expression of $m$ GluR2 mRNA in prefrontal cortex [53] and cerebellum [112] in schizophrenics. Further investigation in larger samples is required to determine the level of expression of $m G l u R 2$ mRNA in schizophrenia brain, as well as to test whether chronic antipsychotics have a significant effect on $m G l u R 2$ mRNA expression.

Discrepant results have been published regarding the level of expression of mGluR2/3 protein in prefrontal cortex, with unaffected [113] and higher [114] mGluR2/3 immunoreactivity in antipsychotic-treated schizophrenic subjects. It has been reported that the density of mGluR2/3 binding sites is lower in cortex from young untreated schizophrenic subjects [53], and recent findings by semi-quantitative western blot assay suggest a reduction in mGluR3 protein in prefrontal cortex in schizophrenic subjects, with mGluR2 protein levels unchanged [115]. Much evidence indicates that metabotropic glutamate receptors exist and function as heterodimers, and the amino terminus ligand-binding domain presents a disulphide bridge connecting the two protomers (see above). Thus, it is reasonable to speculate that metabotropic glutamate receptors are expressed as dimers in the cell membrane under physiological conditions. However, the level of expression of mGluR3 as dimer has been reported to be significantly lower in prefrontal cortex of schizophrenic subjects, whereas total mGluR3 protein was not altered significantly [116]. The unaffected level of expression of $m G l u R 3$ mRNA in schizophrenia brain, as well as the mGluR2-dependent mechanism of action of glutamate antipsychotics in mouse models (see above), makes necessary further investigation of the level of expression and function of mGluR2 and mGluR3 in postmortem human brain of schizophrenic subjects and controls.

\section{Conclusions and future directions}

Multidisciplinary approaches suggest that mGluR2, and not mGluR3, is the target of metabotropic glutamate antipsychotics in mouse models. Further investigation is necessary to better understand the molecular and cellular mechanisms by which mGluR2 activation elicits antipsychotic effects. Whereas the etiology of schizophrenia clearly involves genetic factors, inheritance alone is not sufficient for clinical manifestation of schizophrenia, and considerations of the etiology of schizophrenia also include the role of environmental factors. Several approaches have reported that factors such as obstetric complications [117,118], maternal infection [119,120], and prenatal malnutrition [121] influence schizophrenia risk. Interestingly, recent findings suggest that GRM3 gene interacts with obstetric complications to affect the risk of schizophrenia [122]. However, the genetic data available so far are fragmented to fully validate the associations between the polymorphic GRM3 gene and schizophrenia. A better understanding of the genetic and epigenetic mechanisms that regulate the level of expression and function of mGluR2 and mGluR3 in schizophrenia brain will not only continue a fascinating new chapter in neurobiology and molecular psychiatry, but might also ultimately lead to the identification of entirely new classes of antipsychotic drugs.

\section{Acknowledgments}

This work was supported by NIMH R01 MH084894 (J.G.M), NIDA P01 DA12923 (S.C.S.) and NARSAD (J.G.M). J.L.M. was recipient of a postdoctoral fellowship from Ministerio de Ciencia e Innovación, Spain.

\section{References}

1. Freedman R. Schizophrenia. N Engl J Med 2003;349:1738-1749. [PubMed: 14585943] 
2. Sawa A, Snyder SH. Schizophrenia: neural mechanisms for novel therapies. Mol Med 2003;9:3-9. [PubMed: 12765334]

3. Tamminga CA, Holcomb HH. Phenotype of schizophrenia: a review and formulation. Mol Psychiatry 2005;10:27-39. [PubMed: 15340352]

4. Ross CA, Margolis RL, Reading SA, Pletnikov M, Coyle JT. Neurobiology of schizophrenia. Neuron 2006;52:139-153. [PubMed: 17015232]

5. Lang UE, Puls I, Muller DJ, Strutz-Seebohm N, Gallinat J. Molecular mechanisms of schizophrenia. Cell Physiol Biochem 2007;20:687-702. [PubMed: 17982252]

6. Lehmann HE, Hanrahan GE. Chlorpromazine; new inhibiting agent for psychomotor excitement and manic states. AMA Arch Neurol Psychiatry 1954;71:227-237.

7. Granger B, Albu S. The haloperidol story. Ann Clin Psychiatry 2005;17:137-140. [PubMed: 16433054]

8. Crilly J. The history of clozapine and its emergence in the US market: a review and analysis. His Psychiatry 2007;18:30-60.

9. Hippius H. A historical perspective of clozapine. J Clin Psychiatry 1999;60(suppl 12):22-23. [PubMed: 10372606]

10. Purdon SE, Malla A, Labelle A, Lit W. Neuropsychological change in patients with schizophrenia after treatment with quetiapine or haloperidol. J Psychiatry Neurosci 2001;26:137-149. [PubMed: 11291531]

11. Nasrallah H. A review of the effect of atypical antipsychotics on weight. Psychoneuroendocrinology 2003;28(suppl 1):83-96. [PubMed: 12504074]

12. Kapur S, Remington G. Atypical antipsychotics: new directions and new challenges in the treatment of schizophrenia. Annu Rev Med 2001;52:503-517. [PubMed: 11160792]

13. Lieberman JA, Bymaster FP, Meltzer HY, Deutch AY, Duncan GE, Marx CE, Aprille JR, Dwyer DS, Li XM, Mahadik SP, Duman RS, Porter JH, Modica-Napolitano JS, Newton SS, Csernansky JG. Antipsychotic drugs: comparison in animal models of efficacy, neurotransmitter regulation, and neuroprotection. Pharmacol Rev 2008;60:358-403. [PubMed: 18922967]

14. Miyamoto S, Duncan GE, Marx CE, Lieberman JA. Treatments for schizophrenia: a critical review of pharmacology and mechanisms of action of antipsychotic drugs. Mol Psychiatry 2005;10:79-104. [PubMed: 15289815]

15. Gray JA, Roth BL. Molecular targets for treating cognitive dysfunction in schizophrenia. Schizophr Bull 2007;33:1100-1119. [PubMed: 17617664]

16. Lamberti JS, Olson D, Crilly JF, Olivares T, Williams GC, Tu X, Tang W, Wiener K, Dvorin S, Dietz MB. Prevalence of the metabolic syndrome among patients receiving clozapine. Am J Psychiatry 2006;163:1273-1276. [PubMed: 16816234]

17. Shirzadi AA, Ghaemi SN. Side effects of atypical antipsychotics: extrapyramidal symptoms and the metabolic syndrome. Harv Rev Psychiatry 2006;14:152-164. [PubMed: 16787887]

18. Haddad PM, Sharma SG. Adverse effects of atypical antipsychotics: differential risk and clinical implications. CNS Drugs 2007;21:911-936. [PubMed: 17927296]

19. Nasrallah HA. Atypical antipsychotic-induced metabolic side effects: insights from receptor-binding profiles. Mol Psychiatry 2008;13:27-35. [PubMed: 17848919]

20. Marek GJ. Metabotropic glutamate 2/3 receptors as drug targets. Curr Opin Pharmacol 2004;4:1822. [PubMed: 15018834]

21. Sodhi M, Wood KH, Meador-Woodruff J. Role of glutamate in schizophrenia: integrating excitatory avenues of research. Expert Rev Neurother 2008;8:1389-1406. [PubMed: 18759551]

22. Krivoy A, Fischel T, Weizman A. The possible involvement of metabotropic glutamate receptors in schizophrenia. Eur Neuropsychopharmacol 2008;18:395-405. [PubMed: 18063347]

23. Harrison PJ, Lyon L, Sartorius LJ, Burnet PW, Lane TA. The group II metabotropic glutamate receptor 3 (mGluR3, mGlu3, GRM3): expression, function and involvement in schizophrenia. J Psychopharmacol 2008;22:308-322. [PubMed: 18541626]

24. Conn PJ, Lindsley CW, Jones CK. Activation of metabotropic glutamate receptors as a novel approach for the treatment of schizophrenia. Trends Pharmacol Sci 2009;30:25-31. [PubMed: 19058862] 
25. Patil ST, Zhang L, Martenyi F, Lowe SL, Jackson KA, Andreev BV, Avedisova AS, Bardenstein LM, Gurovich IY, Morozova MA, Mosolov SN, Neznanov NG, Reznik AM, Smulevich AB, Tochilov VA, Johnson BG, Monn JA, Schoepp DD. Activation of mGlu2/3 receptors as a new approach to treat schizophrenia: a randomized Phase 2 clinical trial. Nat Med 2007;13:1102-1107. [PubMed: 17767166]

26. Petronis A. The origin of schizophrenia: genetic thesis, epigenetic antithesis, and resolving synthesis. Biol Psychiatry 2004;55:965-970. [PubMed: 15121478]

27. Harrison PJ, Weinberger DR. Schizophrenia genes, gene expression, and neuropathology: on the matter of their convergence. Mol Psychiatry 2005;10:40-68. image 45. [PubMed: 15263907]

28. Chen PE, Wyllie DJ. Pharmacological insights obtained from structure-function studies of ionotropic glutamate receptors. Br J Pharmacol 2006;147:839-853. [PubMed: 16474411]

29. Foord SM, Bonner TI, Neubig RR, Rosser EM, Pin JP, Davenport AP, Spedding M, Harmar AJ. International Union of Pharmacology. XLVI. G protein-coupled receptor list. Pharmacol Rev 2005;57:279-288. [PubMed: 15914470]

30. Kristiansen K. Molecular mechanisms of ligand binding, signaling, and regulation within the superfamily of G-protein-coupled receptors: molecular modeling and mutagenesis approaches to receptor structure and function. Pharmacol Ther 2004;103:21-80. [PubMed: 15251227]

31. Pin JP, Galvez T, Prezeau L. Evolution, structure, and activation mechanism of family 3/C G-proteincoupled receptors. Pharmacol Ther 2003;98:325-354. [PubMed: 12782243]

32. Conn PJ, Pin JP. Pharmacology and functions of metabotropic glutamate receptors. Annu Rev Pharmacol Toxicol 1997;37:205-237. [PubMed: 9131252]

33. Whorton MR, Bokoch MP, Rasmussen SG, Huang B, Zare RN, Kobilka B, Sunahara RK. A monomeric $\mathrm{G}$ protein-coupled receptor isolated in a high-density lipoprotein particle efficiently activates its G protein. Proc Natl Acad Sci USA 2007;104:7682-7687. [PubMed: 17452637]

34. Chabre M, le Maire M. Monomeric G-protein-coupled receptor as a functional unit. Biochemistry 2005;44:9395-9403. [PubMed: 15996094]

35. Bayburt TH, Leitz AJ, Xie G, Oprian DD, Sligar SG. Transducin activation by nanoscale lipid bilayers containing one and two rhodopsins. J Biol Chem 2007;282:14875-14881. [PubMed: 17395586]

36. Ernst OP, Gramse V, Kolbe M, Hofmann KP, Heck M. Monomeric G protein-coupled receptor rhodopsin in solution activates its $\mathrm{G}$ protein transducin at the diffusion limit. Proc Natl Acad Sci USA 2007;104:10859-10864. [PubMed: 17578920]

37. Leitz AJ, Bayburt TH, Barnakov AN, Springer BA, Sligar SG. Functional reconstitution of Beta2adrenergic receptors utilizing self-assembling Nanodisc technology. Biotechniques 2006;40:601602. 604, 606. [PubMed: 16708760]

38. Jastrzebska B, Fotiadis D, Jang GF, Stenkamp RE, Engel A, Palczewski K. Functional and structural characterization of rhodopsin oligomers. J Biol Chem 2006;281:11917-11922. [PubMed: 16495215]

39. Pin JP, Neubig R, Bouvier M, Devi L, Filizola M, Javitch JA, Lohse MJ, Milligan G, Palczewski K, Parmentier M, Spedding M. International Union of Basic and Clinical Pharmacology. LXVII. Recommendations for the recognition and nomenclature of $\mathrm{G}$ protein-coupled receptor heteromultimers. Pharmacol Rev 2007;59:5-13. [PubMed: 17329545]

40. Terrillon S, Bouvier M. Roles of G-protein-coupled receptor dimerization. EMBO Rep 2004;5:3034. [PubMed: 14710183]

41. Milligan G. G protein-coupled receptor dimerisation: molecular basis and relevance to function. Biochim Biophys Acta 2007;1768:825-835. [PubMed: 17069751]

42. Bowery NG, Enna SJ. Gamma-aminobutyric acid(B) receptors: first of the functional metabotropic heterodimers. J Pharmacol Exp Ther 2000;292:2-7. [PubMed: 10604925]

43. Pin JP, Kniazeff J, Binet V, Liu J, Maurel D, Galvez T, Duthey B, Havlickova M, Blahos J, Prezeau L, Rondard P. Activation mechanism of the heterodimeric GABA(B) receptor. Biochem Pharmacol 2004;68:1565-1572. [PubMed: 15451400]

44. Galvez T, Duthey B, Kniazeff J, Blahos J, Rovelli G, Bettler B, Prezeau L, Pin JP. Allosteric interactions between GB1 and GB2 subunits are required for optimal GABA(B) receptor function. EMBO J 2001;20:2152-2159. [PubMed: 11331581] 
45. Kniazeff J, Bessis AS, Maurel D, Ansanay H, Prezeau L, Pin JP. Closed state of both binding domains of homodimeric mGlu receptors is required for full activity. Nat Struct Mol Biol 2004;11:706-713. [PubMed: 15235591]

46. Maurel D, Comps-Agrar L, Brock C, Rives ML, Bourrier E, Ayoub MA, Bazin H, Tinel N, Durroux T, Prezeau L, Trinquet E, Pin JP. Cell-surface protein-protein interaction analysis with time-resolved FRET and snap-tag technologies: application to GPCR oligomerization. Nat Methods 2008;5:561567. [PubMed: 18488035]

47. Brock C, Oueslati N, Soler S, Boudier L, Rondard P, Pin JP. Activation of a dimeric metabotropic glutamate receptor by intersubunit rearrangement. J Biol Chem 2007;282:33000-33008. [PubMed: 17855348]

48. Kunishima N, Shimada Y, Tsuji Y, Sato T, Yamamoto M, Kumasaka T, Nakanishi S, Jingami H, Morikawa K. Structural basis of glutamate recognition by a dimeric metabotropic glutamate receptor. Nature 2000;407:971-977. [PubMed: 11069170]

49. Tsuchiya D, Kunishima N, Kamiya N, Jingami H, Morikawa K. Structural views of the ligand-binding cores of a metabotropic glutamate receptor complexed with an antagonist and both glutamate and Gd3+ Proc Natl Acad Sci USA 2002;99:2660-2665. [PubMed: 11867751]

50. Gama L, Wilt SG, Breitwieser GE. Heterodimerization of calcium sensing receptors with metabotropic glutamate receptors in neurons. J Biol Chem 2001;276:39053-39059. [PubMed: 11489900]

51. Ferre S, Karcz-Kubicha M, Hope BT, Popoli P, Burgueno J, Gutierrez MA, Casado V, Fuxe K, Goldberg SR, Lluis C, Franco R, Ciruela F. Synergistic interaction between adenosine A2A and glutamate mGlu5 receptors: implications for striatal neuronal function. Proc Natl Acad Sci USA 2002;99:11940-11945. [PubMed: 12189203]

52. Cabello N, Gandia J, Bertarelli DC, Watanabe M, Lluis C, Franco R, Ferre S, Lujan R, Ciruela F. Metabotropic glutamate type 5, dopamine $\mathrm{D}(2)$ and adenosine $\mathrm{a}(2 \mathrm{a})$ receptors form higher-order oligomers in living cells. J Neurochem. 2009 (in press).

53. Gonzalez-Maeso J, Ang RL, Yuen T, Chan P, Weisstaub NV, Lopez-Gimenez JF, Zhou M, Okawa Y, Callado LF, Milligan G, Gingrich JA, Filizola M, Meana JJ, Sealfon SC. Identification of a serotonin/glutamate receptor complex implicated in psychosis. Nature 2008;452:93-97. [PubMed: 18297054]

54. Gonzalez-Maeso J, Sealfon SC. Agonist-trafficking and hallucinogens. Curr Med Chem 2009;16:1017-1027. [PubMed: 19275609]

55. Geyer MA, Ellenbroek B. Animal behavior models of the mechanisms underlying antipsychotic atypicality. Prog Neuropsychopharmacol Biol Psychiatry 2003;27:1071-1079. [PubMed: 14642967]

56. Powell SB, Geyer MA. Overview of animal models of schizophrenia. Curr Protoc Neurosci 2007; Chapter 9(Unit 9):24. [PubMed: 18428667]

57. Gonzalez-Maeso J, Sealfon SC. Psychedelics and schizophrenia. Trends Neurosci 2009;32:225-232. [PubMed: 19269047]

58. Kristiansen LV, Huerta I, Beneyto M, Meador-Woodruff JH. NMDA receptors and schizophrenia. Curr Opin Pharmacol 2007;7:48-55. [PubMed: 17097347]

59. Geyer MA, Vollenweider FX. Serotonin research: contributions to understanding psychoses. Trends Pharmacol Sci 2008;29:445-453. [PubMed: 19086254]

60. Gonzalez-Maeso J, Weisstaub NV, Zhou M, Chan P, Ivic L, Ang R, Lira A, Bradley-Moore M, Ge Y, Zhou Q, Sealfon SC, Gingrich JA. Hallucinogens recruit specific cortical 5-HT(2A) receptormediated signaling pathways to affect behavior. Neuron 2007;53:439-452. [PubMed: 17270739]

61. Gonzalez-Maeso J, Yuen T, Ebersole BJ, Wurmbach E, Lira A, Zhou M, Weisstaub N, Hen R, Gingrich JA, Sealfon SC. Transcriptome fingerprints distinguish hallucinogenic and nonhallucinogenic 5-hydroxytryptamine $2 \mathrm{~A}$ receptor agonist effects in mouse somatosensory cortex. $\mathrm{J}$ Neurosci 2003;23:8836-8843. [PubMed: 14523084]

62. Moghaddam B, Adams BW. Reversal of phencyclidine effects by a group II metabotropic glutamate receptor agonist in rats. Science 1998;281:1349-1352. [PubMed: 9721099]

63. Gewirtz JC, Marek GJ. Behavioral evidence for interactions between a hallucinogenic drug and group II metabotropic glutamate receptors. Neuropsychopharmacology 2000;23:569-576. [PubMed: 11027922] 
64. Krystal JH, Abi-Saab W, Perry E, D’Souza DC, Liu N, Gueorguieva R, McDougall L, Hunsberger T, Belger A, Levine L, Breier A. Preliminary evidence of attenuation of the disruptive effects of the NMDA glutamate receptor antagonist, ketamine, on working memory by pretreatment with the group II metabotropic glutamate receptor agonist, LY354740, in healthy human subjects.

Psychopharmacology (Berl) 2005;179:303-309. [PubMed: 15309376]

65. Spooren WP, Gasparini F, van der Putten H, Koller M, Nakanishi S, Kuhn R. Lack of effect of LY314582 (a group 2 metabotropic glutamate receptor agonist) on phencyclidine-induced locomotor activity in metabotropic glutamate receptor 2 knockout mice. Eur J Pharmacol 2000;397:R1-R2. [PubMed: 10844118]

66. Fell MJ, Svensson KA, Johnson BG, Schoepp DD. Evidence for the role of metabotropic glutamate (mGlu) 2 not mGlu3 receptors in the preclinical antipsychotic pharmacology of the mGlu2/3 receptor agonist (-)-(1R, 4S, 5S, 6S)-4-amino-2-sulfonylbicyclo[3.1.0]hexane-4, 6-dicarboxylic acid (LY40 4039). J Pharmacol Exp Ther 2008;326:209-217. [PubMed: 18424625]

67. Woolley ML, Pemberton DJ, Bate S, Corti C, Jones DN. The mGlu2 but not the mGlu3 receptor mediates the actions of the mGluR2/3 agonist, LY379268, in mouse models predictive of antipsychotic activity. Psychopharmacology (Berl) 2008;196:431-440. [PubMed: 18057917]

68. Conn PJ, Christopoulos A, Lindsley CW. Allosteric modulators of GPCRs: a novel approach for the treatment of CNS disorders. Nat Rev Drug Discov 2009;8:41-54. [PubMed: 19116626]

69. Galici R, Echemendia NG, Rodriguez AL, Conn PJ. A selective allosteric potentiator of metabotropic glutamate (mGlu) 2 receptors has effects similar to an orthosteric mGlu2/3 receptor agonist in mouse models predictive of antipsychotic activity. J Pharmacol Exp Ther 2005;315:1181-1187. [PubMed: 16123306]

70. Benneyworth MA, Xiang Z, Smith RL, Garcia EE, Conn PJ, Sanders-Bush E. A selective positive allosteric modulator of metabotropic glutamate receptor subtype 2 blocks a hallucinogenic drug model of psychosis. Mol Pharmacol 2007;72:477-484. [PubMed: 17526600]

71. Benneyworth MA, Smith RL, Sanders-Bush E. Chronic phenethylamine hallucinogen treatment alters behavioral sensitivity to a metabotropic glutamate $2 / 3$ receptor agonist. Neuropsychopharmacology 2008;33:2206-2216. [PubMed: 17957214]

72. Bespalov A, Jongen-Relo AL, van Gaalen M, Harich S, Schoemaker H, Gross G. Habituation deficits induced by metabotropic glutamate receptors $2 / 3$ receptor blockade in mice: reversal by antipsychotic drugs. J Pharmacol Exp Ther 2007;320:944-950. [PubMed: 17135347]

73. Wiley JL, Evans RL. Evaluation of age and sex differences in locomotion and catalepsy during repeated administration of haloperidol and clozapine in adolescent and adult rats. Pharmacol Res 2008;58:240-246. [PubMed: 18790058]

74. Sullivan PF, Kendler KS, Neale MC. Schizophrenia as a complex trait: evidence from a meta-analysis of twin studies. Arch Gen Psychiatry 2003;60:1187-1192. [PubMed: 14662550]

75. Consortium TIS. Rare chromosomal deletions and duplications increase risk of schizophrenia. Nature 2008;455:237-241. [PubMed: 18668038]

76. Burmeister M, McInnis MG, Zollner S. Psychiatric genetics: progress amid controversy. Nat Rev Genet 2008;9:527-540. [PubMed: 18560438]

77. Marti SB, Cichon S, Propping P, Nothen M. Human metabotropic glutamate receptor 2 gene (GRM2): chromosomal sublocalization (3p21.1-p21.2) and genomic organization. Am J Med Genet 2002;114:12-14. [PubMed: 11840499]

78. Moises HW, Yang L, Kristbjarnarson H, Wiese C, Byerley W, Macciardi F, Arolt V, Blackwood D, Liu X, Sjogren B, et al. An international two-stage genome-wide search for schizophrenia susceptibility genes. Nat Genet 1995;11:321-324. [PubMed: 7581457]

79. Blouin JL, Dombroski BA, Nath SK, Lasseter VK, Wolyniec PS, Nestadt G, Thornquist M, Ullrich G, McGrath J, Kasch L, Lamacz M, Thomas MG, Gehrig C, Radhakrishna U, Snyder SE, Balk KG, Neufeld K, Swartz KL, DeMarchi N, Papadimitriou GN, Dikeos DG, Stefanis CN, Chakravarti A, Childs B, Housman DE, Kazazian HH, Antonarakis S, Pulver AE. Schizophrenia susceptibility loci on chromosomes 13q32 and 8p21. Nat Genet 1998;20:70-73. [PubMed: 9731535]

80. Faraone SV, Matise T, Svrakic D, Pepple J, Malaspina D, Suarez B, Hampe C, Zambuto CT, Schmitt K, Meyer J, Markel P, Lee H, Harkavy Friedman J, Kaufmann C, Cloninger CR, Tsuang MT. Genome 
scan of European-American schizophrenia pedigrees: results of the NIMH Genetics Initiative and Millennium Consortium. Am J Med Genet 1998;81:290-295. [PubMed: 9674973]

81. Riley BP, McGuffin P. Linkage and associated studies of schizophrenia. Am J Med Genet 2000;97:23-44. [PubMed: 10813802]

82. Ekelund J, Lichtermann D, Hovatta I, Ellonen P, Suvisaari J, Terwilliger JD, Juvonen H, Varilo T, Arajarvi R, Kokko-Sahin ML, Lonnqvist J, Peltonen L. Genome-wide scan for schizophrenia in the Finnish population: evidence for a locus on chromosome 7q22. Hum Mol Genet 2000;9:1049-1057. [PubMed: 10767329]

83. Wedenoja J, Loukola A, Tuulio-Henriksson A, Paunio T, Ekelund J, Silander K, Varilo T, Heikkila K, Suvisaari J, Partonen T, Lonnqvist J, Peltonen L. Replication of linkage on chromosome 7q22 and association of the regional Reelin gene with working memory in schizophrenia families. Mol Psychiatry 2008;13:673-684. [PubMed: 17684500]

84. Joo A, Shibata H, Ninomiya H, Kawasaki H, Tashiro N, Fukumaki Y. Structure and polymorphisms of the human metabotropic glutamate receptor type 2 gene (GRM2): analysis of association with schizophrenia. Mol Psychiatry 2001;6:186-192. [PubMed: 11317221]

85. Kilpatrick GJ, Dautzenberg FM, Martin GR, Eglen RM. 7TM receptors: the splicing on the cake. Trends Pharmacol Sci 1999;20:294-301. [PubMed: 10390648]

86. Ferraguti F, Shigemoto R. Metabotropic glutamate receptors. Cell Tissue Res 2006;326:483-504. [PubMed: 16847639]

87. Sartorius LJ, Nagappan G, Lipska BK, Lu B, Sei Y, Ren-Patterson R, Li Z, Weinberger DR, Harrison PJ. Alternative splicing of human metabotropic glutamate receptor 3. J Neurochem 2006;96:11391148. [PubMed: 16417579]

88. Scherer SW, Duvoisin RM, Kuhn R, Heng HH, Belloni E, Tsui LC. Localization of two metabotropic glutamate receptor genes, GRM3 and GRM8, to human chromosome 7q. Genomics 1996;31:230233. [PubMed: 8824806]

89. Yan WL, Guan XY, Green ED, Nicolson R, Yap TK, Zhang J, Jacobsen LK, Krasnewich DM, Kumra S, Lenane MC, Gochman P, Damschroder-Williams PJ, Esterling LE, Long RT, Martin BM, Sidransky E, Rapoport JL, Ginns EI. Childhood-onset schizophrenia/autistic disorder and $\mathrm{t}(1 ; 7)$ reciprocal translocation: identification of a BAC contig spanning the translocation breakpoint at 7q21. Am J Med Genet 2000;96:749-753. [PubMed: 11121174]

90. Bishop JR, Ellingrod VL, Moline J, Miller D. Association between the polymorphic GRM3 gene and negative symptom improvement during olanzapine treatment. Schizophr Res 2005;77:253-260. [PubMed: 15913960]

91. Egan MF, Straub RE, Goldberg TE, Yakub I, Callicott JH, Hariri AR, Mattay VS, Bertolino A, Hyde TM, Shannon-Weickert C, Akil M, Crook J, Vakkalanka RK, Balkissoon R, Gibbs RA, Kleinman JE, Weinberger DR. Variation in GRM3 affects cognition, prefrontal glutamate, and risk for schizophrenia. Proc Natl Acad Sci USA 2004;101:12604-12609. [PubMed: 15310849]

92. Marenco S, Steele SU, Egan MF, Goldberg TE, Straub RE, Sharrief AZ, Weinberger DR. Effect of metabotropic glutamate receptor 3 genotype on $\mathrm{N}$-acetylaspartate measures in the dorsolateral prefrontal cortex. Am J Psychiatry 2006;163:740-742. [PubMed: 16585454]

93. Nicodemus KK, Kolachana BS, Vakkalanka R, Straub RE, Giegling I, Egan MF, Rujescu D, Weinberger DR. Evidence for statistical epistasis between catechol- $O$-methyltransferase (COMT) and polymorphisms in RGS4, G72 (DAOA), GRM3, and DISC1: influence on risk of schizophrenia. Hum Genet 2007;120:889-906. [PubMed: 17006672]

94. Tan HY, Chen Q, Sust S, Buckholtz JW, Meyers JD, Egan MF, Mattay VS, Meyer-Lindenberg A, Weinberger DR, Callicott JH. Epistasis between catechol- $O$-methyltransferase and type II metabotropic glutamate receptor 3 genes on working memory brain function. Proc Natl Acad Sci USA 2007;104:12536-12541. [PubMed: 17636131]

95. Fujii Y, Shibata H, Kikuta R, Makino C, Tani A, Hirata N, Shibata A, Ninomiya H, Tashiro N, Fukumaki Y. Positive associations of polymorphisms in the metabotropic glutamate receptor type 3 gene (GRM3) with schizophrenia. Psychiatr Genet 2003;13:71-76. [PubMed: 12782962]

96. Chen Q, He G, Wu S, Xu Y, Feng G, Li Y, Wang L, He L. A case-control study of the relationship between the metabotropic glutamate receptor 3 gene and schizophrenia in the Chinese population. Schizophr Res 2005;73:21-26. [PubMed: 15567072] 
97. Mossner R, Schuhmacher A, Schulze-Rauschenbach S, Kuhn KU, Rujescu D, Rietschel M, Zobel A, Franke P, Wolwer W, Gaebel W, Hafner H, Wagner M, Maier W. Further evidence for a functional role of the glutamate receptor gene GRM3 in schizophrenia. Eur Neuropsychopharmacol 2008;18:768-772. [PubMed: 18614340]

98. Marti SB, Cichon S, Propping P, Nothen M. Metabotropic glutamate receptor 3 (GRM3) gene variation is not associated with schizophrenia or bipolar affective disorder in the German population. Am J Med Genet 2002;114:46-50. [PubMed: 11840505]

99. Fallin MD, Lasseter VK, Avramopoulos D, Nicodemus KK, Wolyniec PS, McGrath JA, Steel G, Nestadt G, Liang KY, Huganir RL, Valle D, Pulver AE. Bipolar I disorder and schizophrenia: a 440single-nucleotide polymorphism screen of 64 candidate genes among Ashkenazi Jewish case-parent trios. Am J Hum Genet 2005;77:918-936. [PubMed: 16380905]

100. Norton N, Williams HJ, Dwyer S, Ivanov D, Preece AC, Gerrish A, Williams NM, Yerassimou P, Zammit S, O’Donovan MC, Owen MJ. No evidence for association between polymorphisms in GRM3 and schizophrenia. BMC Psychiatry 2005;5:23. [PubMed: 15892884]

101. Tochigi M, Suga M, Ohashi J, Otowa T, Yamasue H, Kasai K, Kato T, Okazaki Y, Kato N, Sasaki T. No association between the metabotropic glutamate receptor type 3 gene (GRM3) and schizophrenia in a Japanese population. Schizophr Res 2006;88:260-264. [PubMed: 16904291]

102. Bishop JR, Wang K, Moline J, Ellingrod VL. Association analysis of the metabotropic glutamate receptor type 3 gene (GRM3) with schizophrenia. Psychiatr Genet 2007;17:358. [PubMed: 18075480]

103. Schwab SG, Plummer C, Albus M, Borrmann-Hassenbach M, Lerer B, Trixler M, Maier W, Wildenauer DB. DNA sequence variants in the metabotropic glutamate receptor 3 and risk to schizophrenia: an association study. Psychiatr Genet 2008;18:25-30. [PubMed: 18197082]

104. Albalushi T, Horiuchi Y, Ishiguro H, Koga M, Inada T, Iwata N, Ozaki N, Ujike H, Watanabe Y, Someya T, Arinami T. Replication study and meta-analysis of the genetic association of GRM3 gene polymorphisms with schizophrenia in a large Japanese case-control population. Am J Med Genet B Neuropsychiatr Genet 2008;147:392-396. [PubMed: 17948896]

105. Kimchi-Sarfaty C, Oh JM, Kim IW, Sauna ZE, Calcagno AM, Ambudkar SV, Gottesman MM. A "silent" polymorphism in the MDR1 gene changes substrate specificity. Science 2007;315:525528. [PubMed: 17185560]

106. Hollams EM, Giles KM, Thomson AM, Leedman PJ. MRNA stability and the control of gene expression: implications for human disease. Neurochem Res 2002;27:957-980. [PubMed: 12462398]

107. Perkins DO, Jeffries C, Sullivan P. Expanding the 'central dogma': the regulatory role of nonprotein coding genes and implications for the genetic liability to schizophrenia. Mol Psychiatry 2005;10:6978. [PubMed: 15381925]

108. Sartorius LJ, Weinberger DR, Hyde TM, Harrison PJ, Kleinman JE, Lipska BK. Expression of a GRM3 splice variant is increased in the dorsolateral prefrontal cortex of individuals carrying a schizophrenia risk SNP. Neuropsychopharmacology 2008;33:2626-2634. [PubMed: 18256595]

109. Ohnuma T, Augood SJ, Arai H, McKenna PJ, Emson PC. Expression of the human excitatory amino acid transporter 2 and metabotropic glutamate receptors 3 and 5 in the prefrontal cortex from normal individuals and patients with schizophrenia. Brain Res Mol Brain Res 1998;56:207-217. [PubMed: 9602129]

110. Richardson-Burns SM, Haroutunian V, Davis KL, Watson SJ, Meador-Woodruff JH. Metabotropic glutamate receptor mRNA expression in the schizophrenic thalamus. Biol Psychiatry 2000;47:2228. [PubMed: 10650445]

111. Ghose S, Crook JM, Bartus CL, Sherman TG, Herman MM, Hyde TM, Kleinman JE, Akil M. Metabotropic glutamate receptor 2 and 3 gene expression in the human prefrontal cortex and mesencephalon in schizophrenia. Int J Neurosci 2008;118:1609-1627. [PubMed: 18853337]

112. Bullock WM, Cardon K, Bustillo J, Roberts RC, Perrone-Bizzozero NI. Altered expression of genes involved in GABAergic transmission and neuromodulation of granule cell activity in the cerebellum of schizophrenia patients. Am J Psychiatry 2008;165:1594-1603. [PubMed: 18923069]

113. Crook JM, Akil M, Law BC, Hyde TM, Kleinman JE. Comparative analysis of group II metabotropic glutamate receptor immunoreactivity in Brodmann's area 46 of the dorsolateral prefrontal cortex 
from patients with schizophrenia and normal subjects. Mol Psychiatry 2002;7:157-164. [PubMed: 11840308]

114. Gupta DS, McCullumsmith RE, Beneyto M, Haroutunian V, Davis KL, Meador-Woodruff JH. Metabotropic glutamate receptor protein expression in the prefrontal cortex and striatum in schizophrenia. Synapse 2005;57:123-131. [PubMed: 15945063]

115. Ghose S, Gleason KA, Potts BW, Lewis-Amezcua K, Tamminga CA. Differential expression of metabotropic glutamate receptors 2 and 3 in schizophrenia: a mechanism for antipsychotic drug action? Am J Psychiatry. 2009 (in press).

116. Corti C, Crepaldi L, Mion S, Roth AL, Xuereb JH, Ferraguti F. Altered dimerization of metabotropic glutamate receptor 3 in schizophrenia. Biol Psychiatry 2007;62:747-755. [PubMed: 17531207]

117. Cannon M, Jones PB, Murray RM. Obstetric complications and schizophrenia: historical and metaanalytic review. Am J Psychiatry 2002;159:1080-1092. [PubMed: 12091183]

118. Mittal VA, Ellman LM, Cannon TD. Gene-environment interaction and covariation in schizophrenia: the role of obstetric complications. Schizophr Bull 2008;34:1083-1094. [PubMed: 18635675]

119. Patterson PH. Immune involvement in schizophrenia and autism: etiology, pathology and animal models. Behav Brain Res. 2008 (in press).

120. Yolken RH, Torrey EF. Are some cases of psychosis caused by microbial agents? A review of the evidence. Mol Psychiatry 2008;13:470-479. [PubMed: 18268502]

121. Susser E, St Clair D, He L. Latent effects of prenatal malnutrition on adult health: the example of schizophrenia. Ann N Y Acad Sci 2008;1136:185-192. [PubMed: 18579882]

122. Nicodemus KK, Marenco S, Batten AJ, Vakkalanka R, Egan MF, Straub RE, Weinberger DR. Serious obstetric complications interact with hypoxia-regulated/vascular-expression genes to influence schizophrenia risk. Mol Psychiatry 2008;13:873-877. [PubMed: 18195713] 


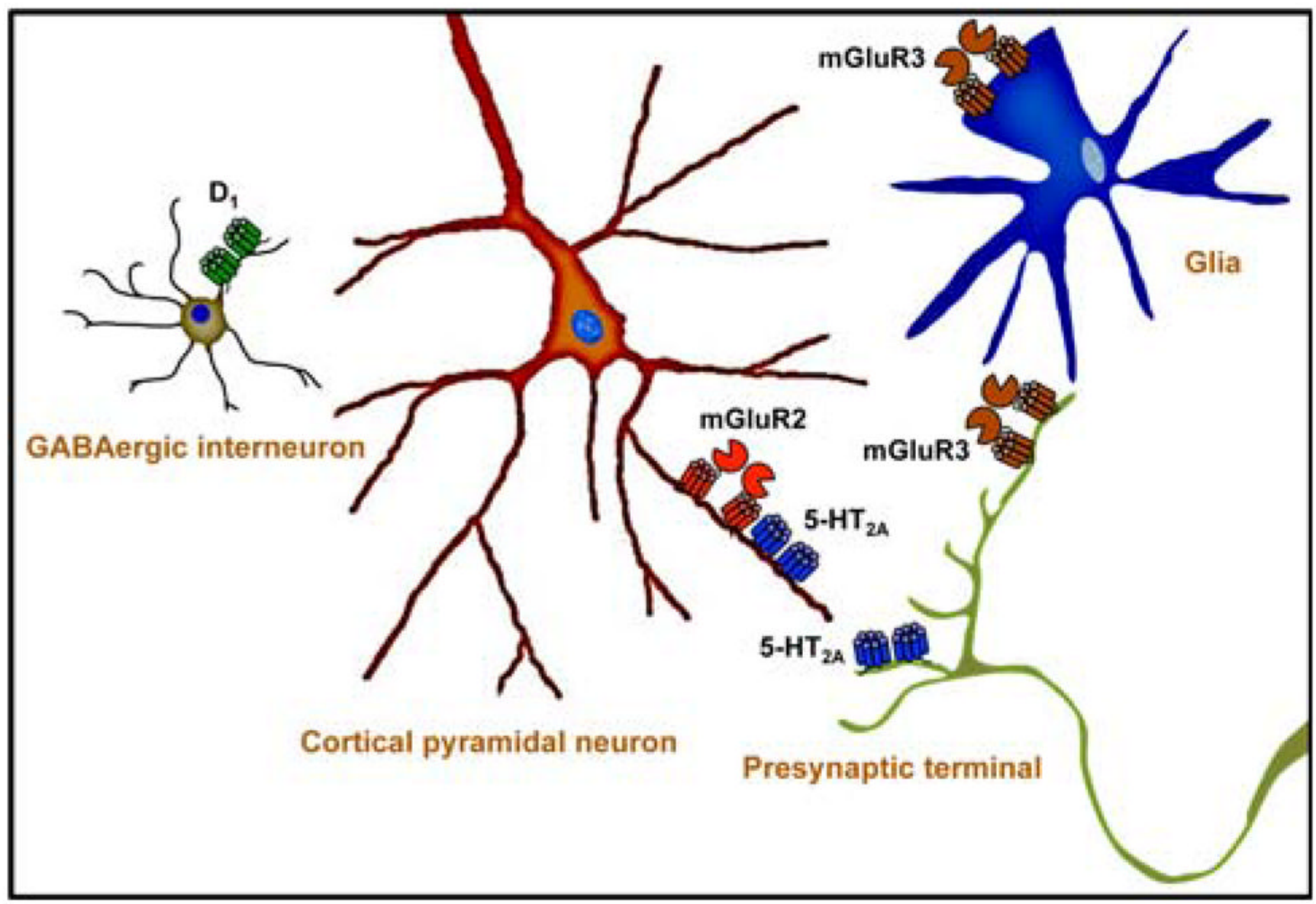

Fig. 1.

This schematic presents a model for the neurotransmitter receptors and cellular subtypes implicated in the mechanism of action of metabotropic glutamate antipsychotics. The mGluR2 and the $5-\mathrm{HT}_{2 \mathrm{~A}}$ co-localize and form a receptor heterocomplex in cortical pyramidal neurons. The mGluR2, and not the mGluR3, is responsible for the antipsychotic-like effects induced by mGluR2/3 agonists in mouse models of schizophrenia. All atypical antipsychotics have in common a high affinity for the $5-\mathrm{HT}_{2 \mathrm{~A}}$ receptor, and a lower affinity for dopaminergic receptors. Further investigation is needed to understand the role of the 5-HT $2 \mathrm{~A}^{-\mathrm{mGluR} 2}$ complex in the mechanism of action of atypical and glutamate antipsychotics, in addition to the cellular signaling pathways and neuronal circuits responsible for the antipsychotic effects. For the purpose of clarity, not all the neurotransmitter receptors implicated in schizophrenia are shown 